\title{
GMR
}

\section{Polymorphism in the melatonin receptor gene in buffalo populations of the Brazilian Amazon}

\author{
E.M. Barbosa ${ }^{1}$, B.B. Souza ${ }^{2}$, R.C. Guimarães ${ }^{2}$, J.S.N. Azevedo ${ }^{3}$, \\ E.C. Gonçalves ${ }^{4}$, H.F.L. Ribeiro ${ }^{2}$, S.T. Rolim Filho ${ }^{2}$ and E. Silva Filho ${ }^{2}$ \\ ${ }^{1}$ Universidade Federal do Amapá, Mazagão, AP, Brasil \\ ${ }^{2}$ Instituto de Saúde e Produção Animal, \\ Universidade Federal Rural da Amazônia, Belém, PA, Brasil \\ ${ }^{3}$ Universidade Federal Rural da Amazônia, Capanema, PA, Brasil \\ ${ }^{4}$ Instituto de Ciências Biológicas, Universidade Federal do Pará, Belém, PA, Brasil \\ Corresponding author: E. Silva Filho \\ E-mail: silva.filho@ufra.edu.br
}

Genet. Mol. Res. 15 (2): gmr.15027960

Received October 29, 2015

Accepted December 9, 2015

Published April 27, 2016

DOI http://dx.doi.org/10.4238/gmr.15027960

\begin{abstract}
Buffalo farming in Brazil is increasing, as is the challenge of identifying molecular markers that will improve productivity. Therefore, the aim of this study was to analyze single nucleotide polymorphisms of the receptor gene for the hormone melatonin in buffaloes from northern Brazil by polymerase chain reactions (PCRs) and restriction fragment length polymorphism assays. The PCR products exhibited a cutting point for $\mathrm{Hpa \textrm {I }}$ at the 318th position of the gene, indicating a transition substitution $(\mathrm{T} \leftrightarrow \mathrm{C})$. This substitution was synonymic, and did not alter the stability of the mRNA structure. Allelic and genotypic frequencies differed between the populations studied, and all of the populations demonstrated endogamy and were in

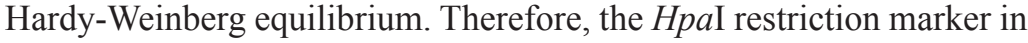
the melatonin receptor gene cannot be used for genetic improvement, but is an excellent marker for population genetic studies.
\end{abstract}

Key words: SNP; PCR-RFLP; Melatonin; Reproduction; Selection 


\section{INTRODUCTION}

Brazil has an effective population size of 1,260,000 buffaloes, and most are farmed in the north of the country (64.1\%). Para State has $36 \%$ of the national population and $56.1 \%$ of the regional population, and is the main producer of buffaloes in Brazil (IBGE, 2012). Domestic buffaloes are resilient animals that possess excellent productive and reproductive indices, high longevity and are able to adapt to unfavorable environments, making buffalo rearing economically viable in several regions of Brazil (Camargo Júnior et al., 2012).

In regions far from the Equator, the river buffalo (Bubalus bubalis) exhibits seasonal polyestrous behavior, with short days and a hiatus in cyclicality during the summer. However, in regions close to the Equator, particularly in the Amazon region, buffaloes exhibit continuous polyestrous behavior (Vale and Ribeiro, 2005). Therefore, seasonal effects may be associated with the activity of the hormone melatonin, which is produced by the pineal gland and inhibits the production of gonadotropin-releasing hormone $(\mathrm{GnRH})$, follicle-stimulating hormone, and luteinizing hormone (Zicarelli, 1994). However, in the Amazon region, birth rates are highest during specific seasons (Ohashi et al., 2012).

Melatonin regulates the secretion of hypothalamic GnRH (Luridiana et al., 2012), has antioxidant properties, and is associated with follicular development and oocyte quality (Tamura et al., 2008). The melatonin receptor, MTRN1A, may have a stimulatory effect on the reproductive axis of short-day species; studies on various breeds of goat and sheep have demonstrated that polymorphisms in this gene occur in animals with low seasonality (Rocha et al., 2011; Zetouni et al., 2014). Therefore, this study aimed to investigate polymorphisms on exon II of the MTR1A gene by polymerase chain reaction-restriction fragment length polymorphism (PCR-RFLP), and test the stability of mRNA structures in two buffalo populations in the Amazon region.

\section{MATERIAL AND METHODS}

\section{Sampling}

The study complied with the Code of Ethics Protocol 003/2015 (Ethics Committee on Animal Use) and 23084.006321/2015-25 (Federal Rural University of Amazon). A total of 140 buffaloes were included: 35 from Terra Firme (TF) and 105 from Várzea (VA) in the State of Pará, Brazil. Approximately 60 hairs, including their bulbs, were collected from each animal and maintained at $4^{\circ} \mathrm{C}$ until analysis.

\section{PCR-RFLP}

Approximately 40 of the best hair bulbs from each animal were selected, and DNA was extracted using the phenol:chloroform:isoamyl alcohol (25:24:1) method (Sambrook et al., 1989). PCRs were conducted using a 2720 Thermal Cycler (Applied Biosystems), with the forward primer sequence TGTGTTTGTGTTGAGCCTGG and the reverse primer sequence ATGGAGAGGGTTTGCGTTTA (Messer et al., 1997). The $25-\mu \mathrm{L}$ final reaction volume contained $2.5 \mu \mathrm{L} 10 \mathrm{X}$ buffer, $2 \mathrm{Mm} \mathrm{MgCl}_{2}, 1.2 \mathrm{mM}$ each dNTP, $10 \%$ betaine, $5 \mu \mathrm{M}$ of each primer, 2 U Taq polymerase DNA kit (Life Technology, Brazil), and 50-100 ng genomic DNA. The initial denaturation temperature was $95^{\circ} \mathrm{C}$ for $10 \mathrm{~min}$, followed by 50 cycles at $94^{\circ} \mathrm{C}$ for 1 
$\min , 58^{\circ} \mathrm{C}$ for $1 \mathrm{~min}$, and $72^{\circ} \mathrm{C}$ for $1 \mathrm{~min}$, and a final extension at $72^{\circ} \mathrm{C}$ for $10 \mathrm{~min}$. The DNA was stained with GelRed ${ }^{\mathrm{TM}}$ (Biotium, USA) on $1.5 \%$ agarose gel.

Ten samples were randomly selected, and the PCR products were purified using an illustra $^{\mathrm{TM}}$ ExoProStar $^{\mathrm{TM}}$ 1-Step enzyme (GE Healthcare, São Paulo, SP, Brazil), following the manufacturer recommendations. The purified products were sequenced using a BigDye ${ }^{\circledR}$ Direct Cycle Sequencing Kit (Life Technology) in an automatic DNA sequencer (ABI 3500XL, Applied Biosystems). On analyzing the sequences, a restriction site was identified at the 79th position of the HpaI enzyme (New England Biolabs Inc., USA), as was found by Carcangiu et al. (2011) and Zetouni et al. (2014). The remaining PCR products were digested by HpaI according to the manufacturer recommendations and stained with GelRed ${ }^{\mathrm{TM}}$ (Biotium) on $2 \%$ agarose gel.

\section{Statistical analyses}

All of the genotypes were tabulated, and the GENEPOP v.5 program (Raymond and Rousset, 1995) was used to determine genotypic and allelic frequencies, observed homozygosity and heterozygosity frequencies, expected heterozygosity, inbreeding coefficients (Fis), and the Hardy-Weinberg equilibrium. Genetic differentiation and the F statistics of the populations were also determined. Significance was set at the 0.05 level. The mfold web server (Zuker, 2003) was used to analyze the structures of each mRNA for T (wild) and C (mutant) alleles.

\section{RESULTS}

We found a substitution polymorphism of the transition type $(\mathrm{T} \leftrightarrow \mathrm{C})$ in the 318 th position of the 106th codons (AAT or AAC). These codons codify the amino acid asparagine, so the substitution was a silent one; consequently, it did not affect the receptor's functional activity. The mRNA structures created by the T-to-C substitution did not exhibit any molecular instability or energy differentiation (Figure 1).
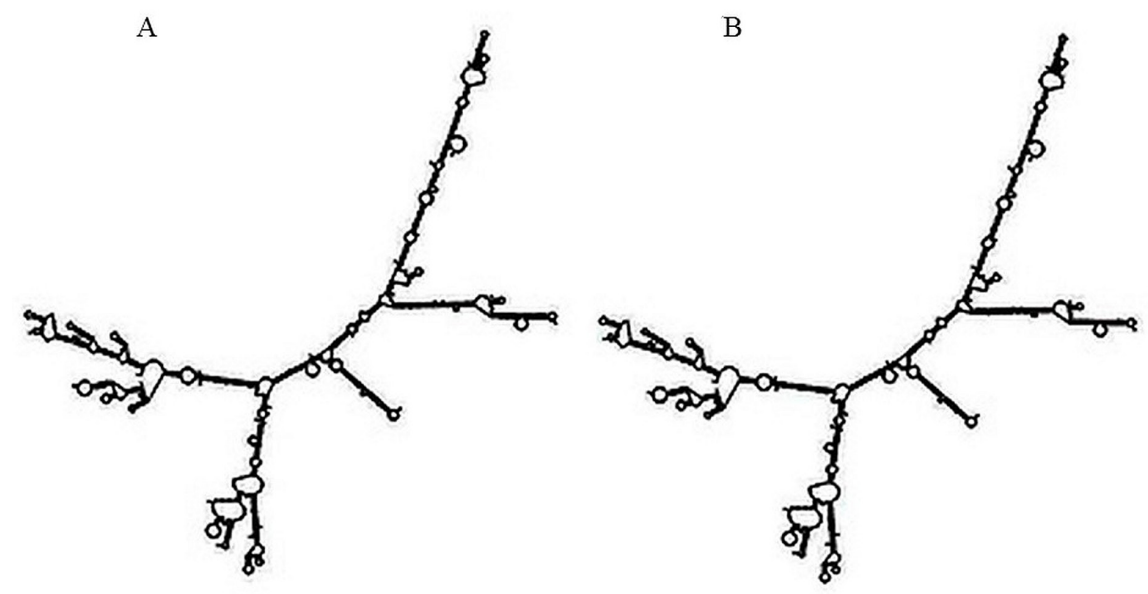

Figure 1. mRNA structure in the melatonin 1 receptor in buffaloes. A. Mutant structure (C at the 318th position). B. Wild structure ( $\mathrm{T}$ at the 318 th position). There was no molecular difference between them. 
All of the 140 animals were genotyped, and all of the possible genotypes were observed (TT, TC, and CC). In the TF population, CT heterozygotes were the most frequent, whereas in the VA population, $\mathrm{CC}$ homozygotes were the most frequent. The $\mathrm{C}$ allele was the most frequent in the TF population, while the T allele was the most frequent in the VA population (Table 1 ). The observed homozygosity was above 0.5 , and, logically, the observed heterozygosity was below 0.5 in both populations. The expected heterozygosity did not differ significantly from the observed heterozygosity, and the two populations did not exhibit any deviation from the Hardy-Weinberg equilibrium $(\mathrm{P}>0.05)$ (Table 1).

Table 1. Population genetic characteristics of two buffalo populations.

\begin{tabular}{l|c|c|c|c|c|c|c}
\hline Group & Genotype (frequency) & Allele (frequency) & HooBs & HeoBs & HeEXP & FIS & HWP \\
\hline \multirow{3}{*}{ TF } & TT $(0.285)$ & $\mathrm{T}(0.529)$ & 0.514 & 0.486 & 0.506 & 0.040 & 1.00 \\
\cline { 2 - 8 } & TC $(0.486)$ & $\mathrm{C}(0.471)$ & & & & & \\
\cline { 2 - 8 } & $\mathrm{CC}(0.229)$ & & & & & & \\
\hline \multirow{3}{*}{ VA } & $\mathrm{TT}(0.124)$ & $\mathrm{T}(0.324)$ & 0.600 & 0.400 & 0.440 & 0.091 & 0.38 \\
\cline { 2 - 8 } & $\mathrm{TC}(0.400)$ & $\mathrm{C}(0.676)$ & & & & & \\
\cline { 2 - 8 } & $\mathrm{CC}(0.476)$ & & & & & \\
\hline
\end{tabular}

$\mathrm{TF}=$ Terra Firme; $\mathrm{VA}=$ Várzea; $\mathrm{Ho}_{\mathrm{OBS}}=$ observed homozygosity; $\mathrm{He}_{\mathrm{OBS}}=$ observed heterozygosity; $\mathrm{He}_{\mathrm{EXP}}=$ expected heterozygosity; $\mathrm{F}_{\mathrm{IS}}=$ inbreeding; $\mathrm{HWP}=$ Hardy-Weinberg probability.

Genetic differentiation between the two populations was significant $(\mathrm{P}<0.05)$, demonstrating an allelic identity in each population. The F-statistic analysis revealed intrapopulation inbreeding $\left(F_{\text {IS }}=0.077\right)$, moderate genetic differentiation between populations $\left(F_{\mathrm{ST}}=0.075\right)$, and inbreeding in general $\left(F_{\mathrm{IT}}=0.147\right)$.

\section{DISCUSSION}

Substitution-type mutations can be classified as transition $(A \leftrightarrow G$ or $C \ll T)$ or transversion (A or $\mathrm{G} \leftrightarrow \mathrm{C}$ or $\mathrm{T}$ ). The substitutions can occur in any part of the genome, and, if they occur in the promoter region of the gene, can alter genetic expression (Kininis and Kraus, 2008). If they occur at the exon or intron level, they can alter the functionality of the protein (Pan et al., 2008) and can destabilize mRNA structure (Sadee et al., 2011). If the substitutions occur in exons, the results can be either synonymic (without altering the amino acid) or not synonymic (the amino acid is altered) (Hunt et al., 2009). Therefore, the single nucleotide polymorphism (SNP) in the 318th position of the melatonin receptor gene in buffaloes was synonymic, as it did not alter the amino acid (asparagine). The SNP did not destabilize the structure of the mRNA, and the wild structure was similar to the mutant structure. Consequently, the translation process was not compromised and the phenotype was the same in the wild type and the mutant. Previous studies that have investigated the HpaI SNP in the melatonin receptor gene in dairy buffaloes have found associations with reproductive characteristics (Carcangiu et al., 2011; Luridiana et al., 2012), although Zetouni et al. (2014) did not find any association between the SNP and reproductive characteristics, which is to be expected for a synonymic marker.

The allelic and genotypic frequencies of the TF buffaloes were similar to those observed by Carcangiu et al. (2011) when studying Italian Mediterranean buffaloes, and to those reported by Zetouni et al. (2014) of a herd of commercial dairy buffaloes from the State of São Paulo, Brazil, all of which differed from the VA population. However, the allelic and genotypic frequencies of the two populations were different to those observed by Luridiana 
et al. (2012) in a herd of Italian Mediterranean buffaloes. The genetic differences between the populations studied may have been a result of selective reproduction and production in both populations, and endogamy, which may be related to small effective population sizes (Malhado et al., 2007).

Therefore, the HpaI SNP in the melatonin receptor gene is not a reliable marker for the selection of buffalo reproductive characteristics in regions with seasonal variation. Future studies should identify markers that are involved in the receptor's control of expression in the promoter region of the gene.

\section{Conflicts of interest}

The authors declare no conflicts of interest.

\section{ACKNOWLEDGMENTS}

We are very grateful for samples provided by producers from Terra Firme and Várzea farms in the State of Pará. We also extend our gratitude to the Laboratório de Tecnologia Biomolecular of the Universidade Federal do Pará for laboratory facilities.

\section{REFERENCES}

Camargo Júnior RNC, Marques JRF, Marcondes CR, Araújo CV, et al. (2012). Indices of reproductive efficiency of buffaloes of the Brazilian Eastern Amazon. Arq. Bras. Med. Vet. Zootec. 64: 796-803.

Carcangiu V, Mura MC, Pazzola M, Vacca GM, et al. (2011). Characterization of the Mediterranean Italian buffaloes melatonin receptor 1A (MTNR1A) gene and its association with reproductive seasonality. Theriogenology 76: 419426. http://dx.doi.org/10.1016/j.theriogenology.2011.02.018

Hunt R, Sauna ZE, Ambudkar SV, Gottesman MM, et al. (2009). Silent (synonymous) SNPs: should we care about them? Methods Mol. Biol. 578: 23-39. http://dx.doi.org/10.1007/978-1-60327-411-1_2

IBGE (Instituto Brasileiro de Geografia e Estatística) (2012). Produção da pecuária municipal, Rio de Janeiro, 40: 1-71.

Kininis M and Kraus WL (2008). A global view of transcriptional regulation by nuclear receptors: gene expression, factor localization, and DNA sequence analysis. Nucl. Recept. Signal. 6: 1-11.

Luridiana S, Mura MC, Pazzola M, Paludo M, et al. (2012). Association between melatonin receptor 1A (MTNR1A) gene polymorphism and the reproductive performance of Mediterranean Italian buffaloes. Reprod. Fertil. Dev. 24: $983-$ 987. http://dx.doi.org/10.1071/RD11297

Malhado CHM, Ramos AA, Carneiro PLS, Souza JC, et al. (2007). Parâmetros e tendências da produção de leite em bubalinos da raça Murrah no Brasil. Rev. Bras. Zootec. 36: 376-379. http://dx.doi.org/10.1590/S1516-35982007000200014

Messer LA, Wang L, Tuggle CK, Yerle M, et al. (1997). Mapping of the melatonin receptor 1a (MTNR1A) gene in pigs, sheep, and cattle. Mamm. Genome 8: 368-370. http://dx.doi.org/10.1007/s003359900444

Ohashi O, Miranda MS, Santos SD, Cordeiro MDS, et al. (2012). Distúrbios reprodutivos do rebanho bubalino nacional. Ciênc. Anim. 22: 171-187.

Pan Q, Shai O, Lee LJ, Frey BJ, et al. (2008). Deep surveying of alternative splicing complexity in the human transcriptome by high-throughput sequencing. Nat. Genet. 40: 1413-1415. http://dx.doi.org/10.1038/ng.259

Raymond M and Rousset F (1995). GENEPOP (version 1.2): population genetics software for exact tests and ecumenicism. J. Hered. 86: 248-249.

Rocha RMP, Matos MHTM, Lima LF, Saraiva MVA, et al. (2011). Melatonina e reprodução animal: implicações na fisiologia ovariana. Acta Vet. Bras. 5: 147-157.

Sadee W, Wang D, Papp AC, Pinsonneault JK, et al. (2011). Pharmacogenomics of the RNA world: structural RNA polymorphisms in drug therapy. Clin. Pharmacol. Ther. 89: 355-365. http://dx.doi.org/10.1038/clpt.2010.314

Sambrook J, Fritsch EF and Maniatis T (1989). Molecular cloning, a laboratory manual. 2nd edition. Cold Spring Harbor Laboratory Press, New York.

Tamura H, Nakamura Y, Terron MP, Flores LJ, et al. (2008). Melatonin and pregnancy in the human. Reprod. Toxicol. 25: 
291-303. http://dx.doi.org/10.1016/j.reprotox.2008.03.005

Vale WG and Ribeiro HFL (2005). Características reprodutivas dos bubalinos: puberdade, ciclo estral, involução uterina e atividade ovariana no pós-parto. Vet. Bras. Reprod. Anim. 29: 63-73.

Zetouni L, de Camargo GM, da Silva Fonseca PD, Cardoso DF, et al. (2014). Polymorphisms in the MTRN1A gene and their effects on the productive and reproductive traits in buffaloes. Trop. Anim. Health Prod. 46: 337-340. http:// dx.doi.org/10.1007/s11250-013-0493-1

Zicarelli L (1994). Management in different environmental condition. Buffalo J. 44: 17-38.

Zuker M (2003). Mfold web server for nucleic acid folding and hybridization prediction. Nucleic Acids Res. 31: 34063415. http://dx.doi.org/10.1093/nar/gkg595 